\title{
Cloning, sequencing, and polymorphisms of the Wistar-Imamichi rat growth hormone gene using PCR-SSCP
}

\author{
M.Q. Liu ${ }^{1}$, J.G. Wang ${ }^{2 *}$ and X.L. Li $^{2 *}$ \\ ${ }^{1}$ College of Life Science, Hohhot, Inner Mongolia, China \\ ${ }^{2}$ Key Laboratory of National Education Ministry for Mammalian \\ Reproductive Biology and Biotechnology, Inner Mongolia University, \\ Hohhot, Inner Mongolia, China \\ *These authors contributed equally to this study. \\ Corresponding author: X.L. Li \\ E-mail: lixueling@hotmail.com
}

Genet. Mol. Res. 12 (4): 6203-6211 (2013)

Received November 8, 2012

Accepted May 10, 2013

Published December 4, 2013

DOI http://dx.doi.org/10.4238/2013.December.4.7

\begin{abstract}
We successfully cloned the Wistar-Imamichi (WI) rat growth hormone gene (GenBank accession: GQ890681), which contained 5 exons and 4 introns. Using the polymerase chain reactionsingle-strand conformation polymorphism (PCR-SSCP) technique, a novel missense substitution single nucleotide polymorphism was identified and tested for Hardy-Weinberg equilibrium with the $\chi^{2}$ test. This gene fragment was investigated in 50 adult rats and 50 neonatal rats by PCR-SSCP. Results showed that only intron 4 had a polymorphic locus at the 97th nucleotide position from A (in the AA genotype) to C (in the BB genotype). Further statistical analysis showed that this locus was in Hardy-Weinberg equilibrium. These results suggested that this specific pathogen-free WI rat population, which was bred in the barrier system of the Research Center for Laboratory Animal Science of Inner Mongolia University, has high hereditary stability.
\end{abstract}

Key words: Wistar-Imamichi rat; Growth hormone gene; PCR-SSCP 


\section{INTRODUCTION}

Wistar-Imamichi (WI) rats are an inbred and strictly selected white rat strain, which was originally developed from an American Wistar strain by Japanese scientists in the 1950s. WI rats are currently a popular laboratory animal with several advantageous characteristics, such as early sexual maturity, a stable sexual cycle, high reproductive rates, docility, and drug sensitivity (Shorgan et al., 1991). The WI rat was introduced from Japan by the Center for Laboratory Animal Research of Inner Mongolia University in 1999, where the strain has since been preserved and propagated. Consequently, WI rats are now an isolated and stable group that is widely used in life science and medical research as an animal model.

Growth hormone $(\mathrm{GH})$ is a peptide hormone that stimulates growth and cell reproduction and regeneration in humans and other animals. The rat GH is a 191-amino acid singlechain polypeptide that is synthesized, stored, and secreted by somatotroph cells within the lateral wings of the anterior pituitary gland. The length and sequence of the mammal GH gene is relatively conserved at approximately $2 \mathrm{~kb}$ with 5 exons and 4 introns (Moore et al., 1982; Sun and Zhu, 1999). GH has attracted increasing attention as a functional gene in animal genome studies. In particular, the mammalian GH gene has been deeply investigated (Li et al., 2010). Polymerase chain reaction-single-strand conformation polymorphism (PCR-SSCP) analysis is one of the simplest, and perhaps one of the most sensitive, PCR-based methods for detecting mutations. Orita et al. (1989a,b) developed the PCR-SSCP method as a rapid and sensitive method to detect mutations or polymorphisms in DNA sequences. The PCR products are heat-denatured to single-stranded DNA (ssDNA), and the mutations or polymorphisms can be detected electrophoretically as mobility shifts resulting from a change in the conformation of ssDNA. Using PCR-SSCP technology and GH as a candidate gene, researchers have detected genetic polymorphisms in several animals, including mink (Yao et al., 1996; Malveiro et al., 2001; Li et al., 2010; Bai et al., 2010).

In order to achieve greater understanding of the biological characteristics of WI rats at the genetic and molecular levels, we investigated the WI rat GH gene across different developmental stages. We successfully cloned the WI rat GH gene (GenBank accession: GQ890681), including all 5 exons and 4 introns. We also investigated these gene fragments in 50 adult and 50 neonatal rats by PCR-SSCP. Results showed that only intron 4 had a polymorphic locus at the 97th nucleotide position from A (in the AA genotype) to $\mathrm{C}$ (in the $\mathrm{BB}$ genotype). Further statistical analysis showed that this locus was in Hardy-Weinberg equilibrium. These results suggested that this specific pathogen-free (SPF) WI rat population, which is bred in the barrier system of the Center for Laboratory Animal Research of Inner Mongolia University, has high hereditary stability.

\section{MATERIAL AND METHODS}

\section{Animals}

The SPF WI rats used in this study were obtained from the Center for Laboratory Animal Research of Inner Mongolia University.

\section{Genomic DNA extraction}

Genomic DNA of the samples was extracted from $0.2 \mathrm{~g}$ liver using phenol:chloroform: 
isopentanol (25:24:1) and ethanol precipitation. The purity and concentration of the extracted DNA were determined using a spectrophotometer.

\section{Cloning and sequence analysis of the WI rat GH gene}

PCR primers were designed by reference to the rat gene for GH (presomatotropin) of Rattus norvegicus (V01238.1) from GenBank. The total sequence was 2109 bp in length. The primers used were:

5'-primer: Rgh-v 5'-CAG CAC CCT CGA GCC CAG ATT-3'; 3'-primer: Rgh-d 5'GGT GGC AGT TGC CAG AGT AC-3'. The primers were synthesized by Shanghai Sangon Biotech Co., Ltd.

\section{PCR amplification of GH gene exons and introns}

PCR primers for WI rat GH gene exons and introns were designed according to the sequence of the WI rat GH gene, and were synthesized by Shanghai Sangon Biotech Co., Ltd. The primer sequences are shown in Table 1 .

\section{PCR-SSCP analysis of GH gene exons and introns}

To apply PCR-SSCP for mutation screening, the polyacrylamide gel electrophoresis (PAGE) conditions must be optimized to be highly specific for the target PCR products (Hayashi, 1992). We used a 12-15\% polyacrylamide:bis ratio (29:1) for the different exons and introns. At room temperature, $3 \mu \mathrm{L}$ of each PCR product was supplemented with $7 \mu \mathrm{L}$ SSCP loading buffer $(9.8 \mathrm{~mL}$ deionized formamide, $0.01 \mathrm{M}$ EDTA, $0.025 \%$ xylene cyanol FF, and $0.025 \%$ bromophenol blue). The mixture was denatured at $98^{\circ} \mathrm{C}$ for $10 \mathrm{~min}$ and then immediately chilled on ice and maintained at $-20^{\circ} \mathrm{C}$ for $15 \mathrm{~min}$. The heat-denatured DNA was loaded onto an acrylamide gel with loading buffer and electrophoresed at $4^{\circ} \mathrm{C}$ and $160 \mathrm{~V}$ for $16 \mathrm{~h}$. After electrophoresis, the gel was rinsed in distilled water for $3 \mathrm{~min}$ and fixed in $70 \%$ alcohol for $30 \mathrm{~min}$. The gel was then rinsed again in water and bleached in $1 \% \mathrm{HNO}_{3}$ for $10 \mathrm{~min}$. After rinsing in water 2-3 more times, the gel was stained with $1 \% \mathrm{AgNO}_{3}$ for $30 \mathrm{~min}$. The gel was developed in $2 \% \mathrm{Na}_{2} \mathrm{CO}_{3}$ with formaldehyde until bands were viewed clearly, at which point development was stopped with $70 \%$ acetic acid.

\section{Statistical evaluation of WI rat GH gene polymorphisms}

Genotype frequencies were calculated based on the following formula:

$$
\mathrm{p}=\frac{2 \mathrm{n}_{\mathrm{AA}}+\mathrm{n}_{\mathrm{AB}}}{2\left(\mathrm{n}_{\mathrm{AA}}+\mathrm{n}_{\mathrm{AB}}+\mathrm{n}_{\mathrm{BB}}\right)} \quad \mathrm{q}=\frac{2 \mathrm{n}_{\mathrm{BB}}+\mathrm{n}_{\mathrm{AB}}}{2\left(\mathrm{n}_{\mathrm{AA}}+\mathrm{n}_{\mathrm{AB}}+\mathrm{n}_{\mathrm{BB}}\right)} \quad \text { (Equation 1) }
$$

where $p$ is the $\mathrm{A}$ allele frequency, $q$ is the $\mathrm{B}$ allele frequency. $n A A, n A B$ and $n B B$ are numbers of $\mathrm{AA}, \mathrm{AB}$ and $\mathrm{BB}$. 
Sequences were tested for deviations from Hardy-Weinberg equilibrium with the chisquared $\left(\chi^{2}\right)$ test. When the degrees of freedom (d.f.) $=2$ or the theoretical frequency was below 5 , the following correction formula was used:

$$
\chi^{2}=\sum_{i}^{n}\left(\left|O_{i}-E_{i}\right|-\frac{1}{2}\right)^{2} / E_{i}
$$

where d.f. $=2, \chi_{0.05}^{2}=5.99, \chi_{0.01}^{2}=9.21 ; O_{i}$ is observational frequency; $E_{i}$ is expectation frequency.

\section{RESULTS}

\section{Cloning and sequencing analysis of the WI rat GH gene}

Using the R. norvegicus (Norway rat) GH gene sequence (V01238) from GenBank as reference, we designed and synthesized two PCR primers to amplify the WI rat GH gene sequence. The expected PCR product was approximately $1954 \mathrm{bp}$ in length. Genomic DNA was extracted from 5 adult WI rats and used as a template for the GH gene in PCR. The PCR products are shown in Figure 1A. The PCR products were gel purified and cloned into the pMD19-T plasmid. Three clones were sent for sequencing, the sequences were compared to the $R$. norvegicus $\mathrm{GH}$ gene sequence to confirm the identity of the fragments obtained, and the length and differences identified are shown in Figure 1B. Sequence comparison and analysis confirmed that we successfully obtained the WI rat GH gene sequence. There were $12 \mathrm{bp}$ differences between the WI rat and $R$. norvegicus sequences with $99.83 \%$ consistency. There was only one nucleotide substitution ( $29 \mathrm{G}-\mathrm{A})$ in exon 1 , while all other differences were in the introns, including 5 nucleotide substitutions ( 3 in intron 2; $541 \mathrm{C}-\mathrm{A}$, $1023 \mathrm{G}-\mathrm{T}$, and $1190 \mathrm{G}-\mathrm{T}$, and 2 in intron 4; $1568 \mathrm{C}-\mathrm{A}$ and $1655 \mathrm{G}-$ ), 2 nucleotide deletions ( 1 in intron $2 ; 1195 \mathrm{C}$, and 1 in intron $3 ; 1489 \mathrm{G}$ ), and 4 nucleotide insertions (all in intron 2; $460 \mathrm{~A}, 467 \mathrm{C}, 560 \mathrm{G}$, and $763 \mathrm{~A}$ ) (Figure 1C). We submitted the sequence to the GenBank database under sequence accession No. GQ890681 (http://www.ncbi.nlm.nih.gov/ sites/entrez $\mathrm{db}=$ nuccore $\& \mathrm{cmd}=$ search\&term $=\mathrm{GQ890681})$. The WI rat GH gene sequence is $2109 \mathrm{bp}$ in length, and contains 5 exons $(117,210,133,183$, and $232 \mathrm{bp})$ and 4 introns (231, 614, 199, and $261 \mathrm{bp})$.

\section{PCR-SSCP analysis of GH gene exons and introns 1 and 3}

All exon and intron sequences of the GH gene from 50 neonatal and 50 adult WI rats were amplified by PCR with the primers listed in Table 1, and the PCR products were denatured and run on 12\% PAGE. The results showed that the electrophoresis bands of all exons and introns 1 and 3 were consistent across all rats, indicating that there were no genetic polymorphisms in the exons, intron 1, or intron 3 of the WI rat GH gene (Figures S1-S14). 
A

B

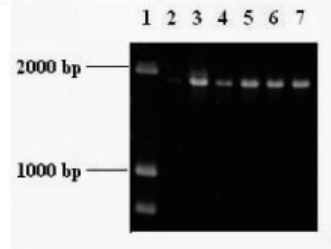

\begin{tabular}{|c|c|c|c|c|c|}
\hline Clone & $\begin{array}{c}\text { Length } \\
(\mathrm{bp})\end{array}$ & $\begin{array}{c}\text { Substitut } \\
\text { ion (bp) }\end{array}$ & $\begin{array}{c}\text { Deletion } \\
(\mathrm{bp})\end{array}$ & $\begin{array}{l}\text { Insertion } \\
(\mathrm{bp})\end{array}$ & $\begin{array}{c}\text { Total } \\
(\mathrm{bp})\end{array}$ \\
\hline 1 & 1943 & 12 & 3 & 3 & 18 \\
\hline 2 & 1942 & 8 & 4 & 3 & 15 \\
\hline 3 & 1941 & 9 & 4 & 2 & 15 \\
\hline
\end{tabular}

C

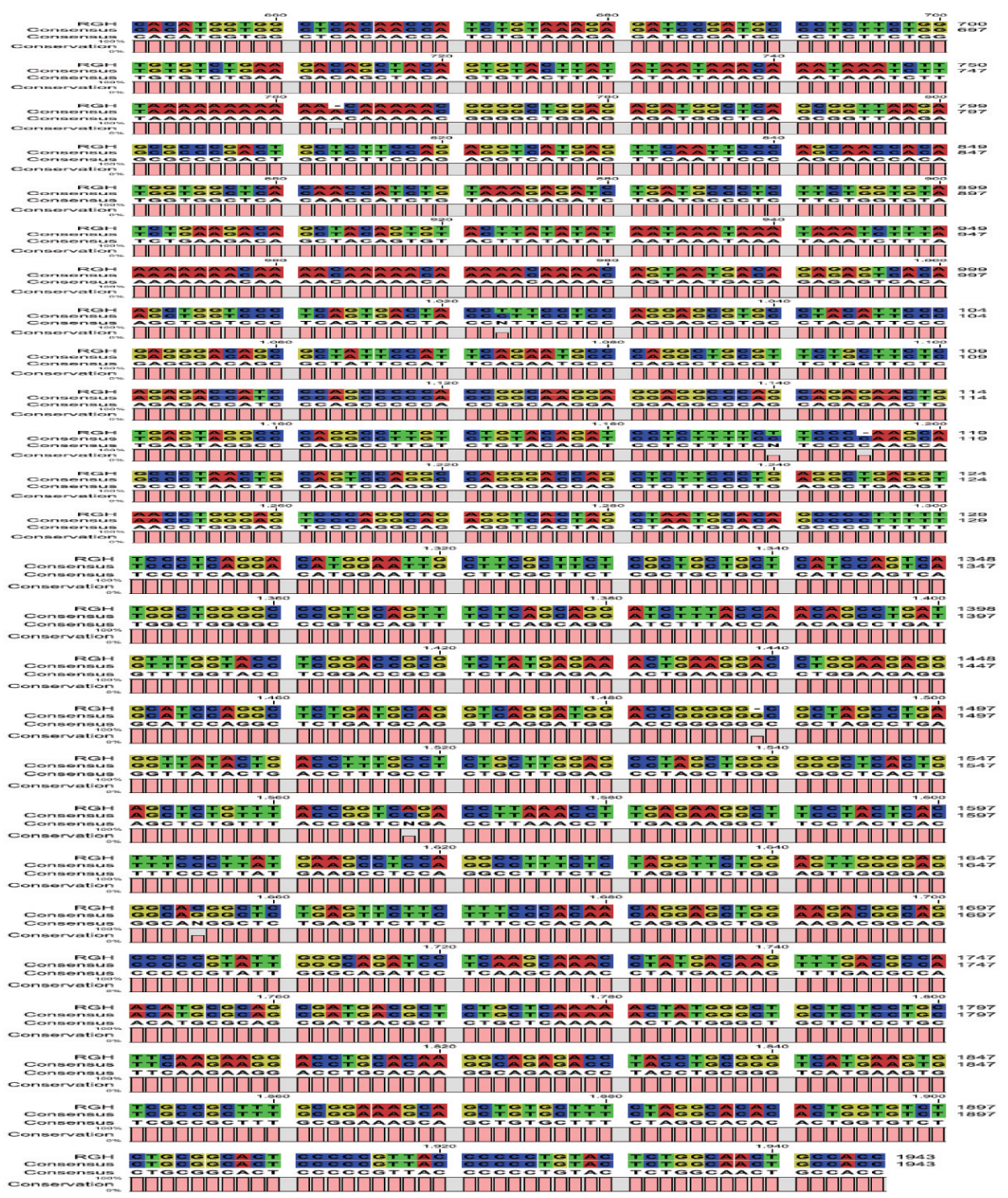

Figure 1. Cloning and sequence analysis for the WI rat growth hormone gene. A. Agarose gel analysis for WI rat GH gene PCR product. B. Difference between three WI rat GH PCR products and Norway rat GH sequence. C. Sequence comparison of the WI rat GH gene and the Norway rat GH gene. 
Table 1. PCR primers for WI rat GH gene exons and introns.

\begin{tabular}{|c|c|c|}
\hline Intron/Exon & Primer sequence & Product length (bp) \\
\hline Exon 1 & $\begin{array}{l}\text { E1-F: 5'-GACCAAATCCAGCACCCT-3' } \\
\text { E1-R: 5'-GTCCAAACCACACCCAGC-3' }\end{array}$ & 117 \\
\hline Exon 2 & $\begin{array}{l}\text { E2-F: 5'-CTCCTCCTGTCCTCCTGTCT-3' } \\
\text { E2-R: 5'-CCAACACCGAGGAACTTACG-3' }\end{array}$ & 210 \\
\hline Exon 3 & $\begin{array}{l}\text { E3-F: 5'-CAGGAGCGTGCCTACATT-3' } \\
\text { E3-R: 5'-TGGGCCTACTCACAGTTCTC-3' }\end{array}$ & 133 \\
\hline Exon 4 & $\begin{array}{l}\text { E4-F: 5'-CTCAGGACATGGAATTGCTT-3' } \\
\text { E4-R: 5'-CCCGGTCCATCCTGACCT-3' }\end{array}$ & 183 \\
\hline Exon 5 & $\begin{array}{l}\text { E5-F: 5'-ACAACAGGAGCTGGAAGACG-3' } \\
\text { E5-R: 5'-TGCCGCAGAGACACCAGT-3' }\end{array}$ & 232 \\
\hline Intron 1 & $\begin{array}{l}\text { I1-F: 5'-CAGATCACTGAGTGGCGATG-3' } \\
\text { Il-R: 5'-AGCCAGGGAGTCTGAGAGTCT-3' }\end{array}$ & 231 \\
\hline Intron 3 & $\begin{array}{l}\text { I3-F: 5'-CCCAGCAGAGAACTGTGAGT-3' } \\
\text { I3-R: 5'-AGCGAGAAGCGAAGCAAT-3' }\end{array}$ & 199 \\
\hline Intron 4 & $\begin{array}{l}\text { I4-F: 5'-CTGATGCAGGTCAGGATG-3' } \\
\text { I4-R: 5'-TGAGGATCTGCCCAATAC-3' }\end{array}$ & 261 \\
\hline
\end{tabular}

\section{PCR-SSCP analysis of intron 4 of the GH gene}

Based on SSCP analysis of 50 adult and 50 neonatal WI rats, genetic polymorphisms of the GH gene were found only in intron 4 (Figures 2 and 3). In adult rats, 29 of the 50 rats were found to be of genotype $\mathrm{AB}, 12$ were of genotype AA, and the other 9 were of genotype BB. Sequence analysis of 2 samples from each group (AA-8 and 9; BB-11 and 12, and AB-18 and 45) showed that the genetic polymorphism of the WI rat GH gene was located at the 97th nucleotide, which is an A in the AA genotype and a C in the BB genotype (Figure 2B). Based on Equation 1 (Material and Methods), the A allele frequency $\left(\mathrm{p}_{\mathrm{A}}\right.$ ) was found to be 0.48 , while the $\mathrm{B}$ allele frequency $\left(\mathrm{q}_{\mathrm{B}}\right)$ was 0.52 . The $\chi^{2}$ test revealed that this WI rat population was in Hardy-Weinberg equilibrium $\left(\chi^{2}=0.9216, \mathrm{P}>0.05\right)$.

The results of the SSCP analysis of intron 4 of the 50 neonatal WI rats are shown in Figure 3. As in the adult rats, the nucleotide substitution was also evident at the 97th nucleotide in the neonatal WI rats: $\mathrm{A}$ in genotype $\mathrm{AA}$ and $\mathrm{C}$ in genotype $\mathrm{BB}$. Of the 50 neonatal rats, 20 were of genotype AB, 6 were of genotype AA, and 24 were of genotype AB. The A allele frequency $\left(\mathrm{p}_{\mathrm{A}}\right)$ was found to be 0.68 , while the $B$ allele frequency $\left(\mathrm{q}_{\mathrm{B}}\right)$ was 0.32 . The $\chi^{2}$ test revealed that the neonatal WI rat population was also in Hardy-Weinberg equilibrium $\left(\chi^{2}=\right.$ 0.1094, $\mathrm{P}>0.05)$.

\section{DISCUSSION}

The experiments of Soreq et al. (1979) investigating all DNA fragments containing the rat GH gene sequence revealed that the transcription unit for the pre-hormone mRNA was approximately $3 \mathrm{~kb}$ in length. The entire difference in size between the human and rat intervening sequences may be accounted for by the presence of a 200-bp direct repeat found in the rat gene (Page et al., 1981). In the present study, we cloned and sequenced the GH gene fragment from WI rats, finding only $12 \mathrm{bp}$ differences. All mutations were found in introns, with one exception in exon 1, which did not result in any amino acid differences in the GH protein. Furthermore, a 200-bp repeat was found in intron 2. 


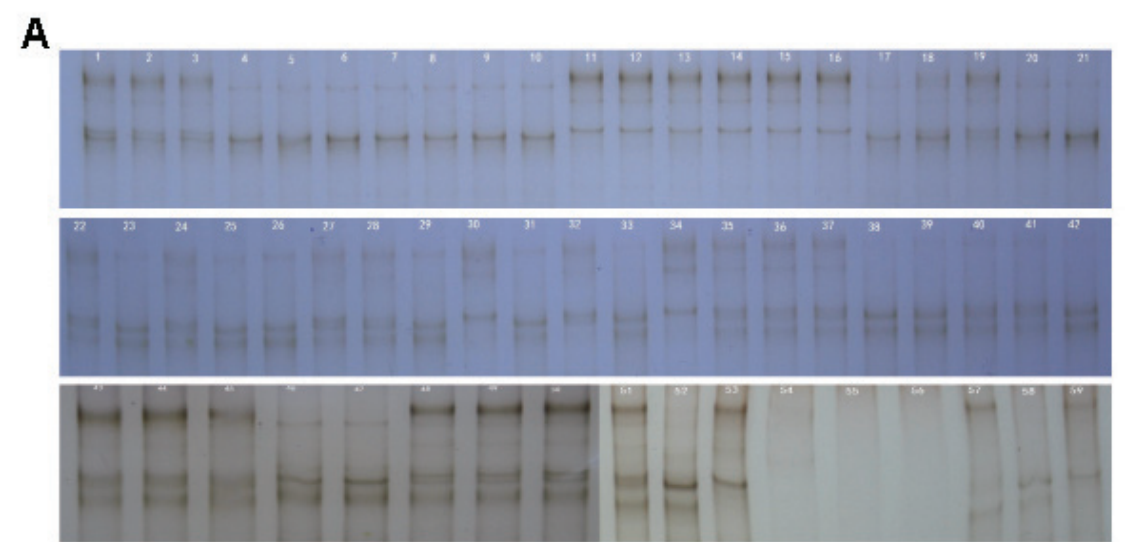

B

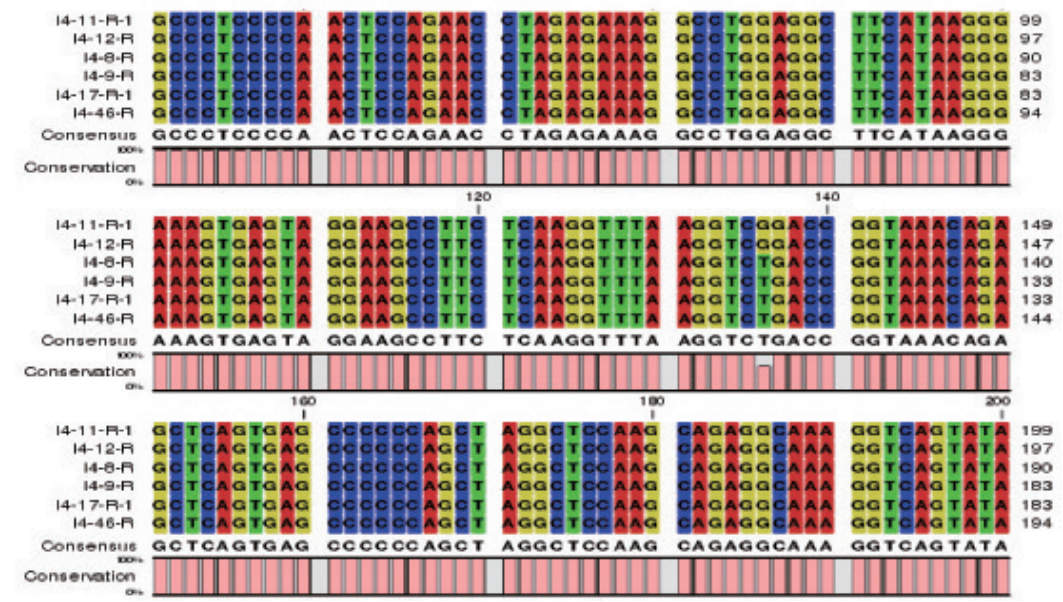

Figure 2. PCR-SSCP and sequence analysis of intron 4 for 50 adult WI rats. A. Lanes 1-50 = PCR-SSCP analysis of intron 4 for 50 adult rats; lanes $51,52,53=$ PCR-SSCP analysis of intron 4 of number 1, 9 and 12; lanes $54,55,56=$ double-strand DNA of intron 4 of 1, 9 and 12; lanes $57,58,59=$ intron 4 of 1,9 and 12 with SSCP loading buffer added, but without denaturation at $98^{\circ} \mathrm{C}$. B. Sequence comparison of two samples from each group.

PCR-SSCP is the electrophoretic separation of single-stranded nucleic acids based on subtle differences in PCR fragment sequences (often a single base pair), enabling determinations of different secondary structures and measurable differences in mobility through the gel. The voltage and temperature of electrophoresis are very important to achieve good band clarity, high repeatability, and stability of single-strand conformation. To maintain stability of the ssDNA 3-D structure, electrophoresis is usually carried out at a low temperature $\left(4^{\circ} \mathrm{C}\right)$. Our experiment was carried out at $4^{\circ} \mathrm{C}$ and $160 \mathrm{~V}$, and the results were clear with obvious confirmation of ssDNA differences. In addition, the length of the PCR fragment could affect mutation detection. If the DNA fragment is 100-300 bp, the SSCP detection rate is approximately $99 \%$. Indeed, the PCR products of most WI rat GH gene exons and introns were within this range, with the exception of intron 2, which was over $600 \mathrm{bp}$, and therefore not suitable for PCR-SSCP analysis. 


\section{A}

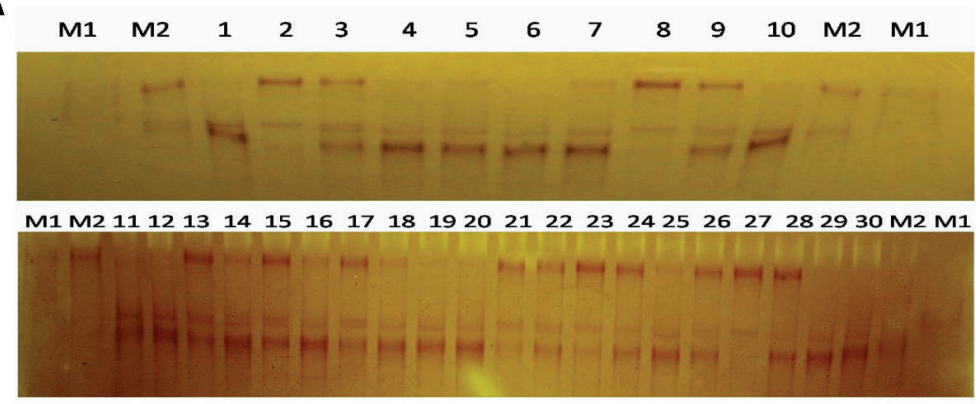

M1 M2 $313233 \quad 3435363738 \quad 394041424344 \quad 45 \quad 4647484950$ M2 M1

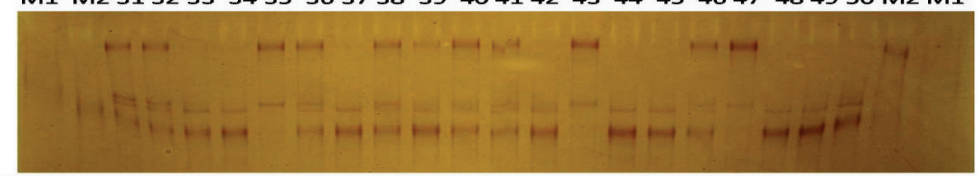

B

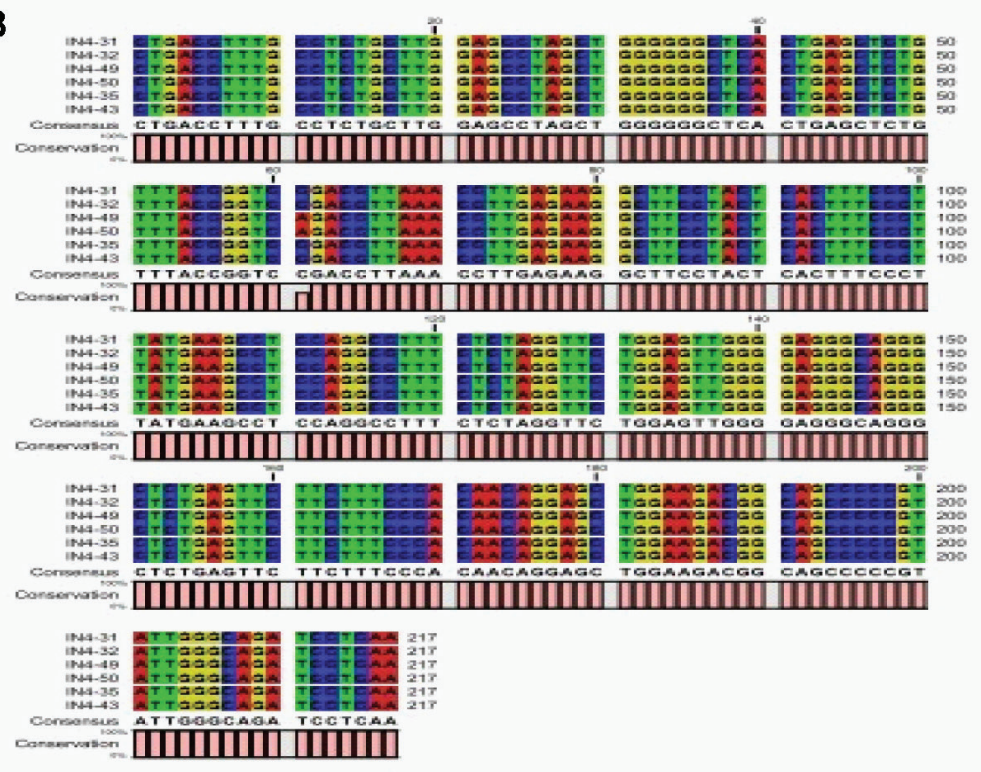

Figure 3. PCR-SSCP and sequence analysis of intron 4 for 50 neonatal WI rats. A. Lanes 1-50 = PCR-SSCP analysis of intron 4 for 50 neonatal rats. Lane $M 1=$ double-strand DNA of intron 4; lane $M 2=$ intron 4 added SSCP loading buffer but without denaturation at $98^{\circ} \mathrm{C}$. B. Sequence comparison of two samples from each group.

Single nucleotide polymorphisms are ubiquitous in animal populations. In this study, we successfully cloned the WI rat GH gene and examined its polymorphisms using the PCRSSCP technique. As a result, we found only one nucleotide substitution in intron 4 at position 97, which was $\mathrm{A}$ in the AA genotype and $\mathrm{C}$ in the BB genotype. Further analysis indicated that the polymorphism at this position was in Hardy-Weinberg equilibrium. These results suggested that the SPF WI rat population that is bred in the barrier system of the Research Center for Laboratory Animal Science of Inner Mongolia University has high hereditary stability. 


\section{ACKNOWLEDGMENTS}

We thank the Research Center for Laboratory Animal Science of Inner Mongolia University for the provision of the WI rats. Research supported by the Science and Technology Project of Inner Mongolia (project \#210062) under the project title "Construction of Standardized Laboratory Animal platform and Analysis of the Biological Characteristics of Wistar-Imamichi Rats".

\section{Supplementary material}

\section{REFERENCES}

Bai J-J, Hu J, Chen S-R and Wang J-Q (2010). PCR-SSCP polymorphism of growth hormone gene in the yak. J. Gansu Ari Univ. 2: 1-5.

Hayashi K (1992). PCR-SSCP: a method for detection of mutations. Genet. Anal. Tech. Appl. 9: 73-79.

Li Y-M, Ding X-M, Yang J-S and Fang H-T (2010). Association analysis of GH gene polymorphism and body mass in mink. Chin. J. Vet. Sci. 12: 266-270.

Malveiro E, Pereira M, Marques PX, Santos IC, et al. (2001). Polymorphisms at the five exons of the growth hormone gene in the algarvia goat: possible association with milk traits. Small. Rumin. Res. 41: 163-170.

Moore DD, Walker MD, Diamond DJ, Conkling MA, et al. (1982). Structure, expression, and evolution of growth hormone genes. Recent Prog. Horm. Res. 38: 197-225.

Orita M, Iwahana H, Kanazawa H, Hayashi K, et al. (1989a). Detection of polymorphisms of human DNA by gel electrophoresis as single-strand conformation polymorphisms. Proc. Natl. Acad. Sci. U. S. A. 86: 2766-2770.

Orita M, Suzuki Y, Sekiya T and Hayashi K (1989b). Rapid and sensitive detection of point mutations and DNA polymorphisms using the polymerase chain reaction. Genomics 5: 874-879.

Page GS, Smith S and Goodman HM (1981). DNA sequence of the rat growth hormone gene: location of the 5 ' terminus of the growth hormone mRNA and identification of an internal transposon-like element. Nucleic Acids Res. 9: 2087-2104.

Shorgan, Zhang S and Xue X (1991). Study on introduced species maitainence and mass reproduction of Wistar-Imamichi rat. Chin. J. Comparative Med. 1: 167-169.

Soreq H, Harpold M, Evans R, Darnell JE Jr, et al. (1979). Rat growth hormone gene: intervening sequences separate the mRNA regions. Nucleic Acids Res. 6: 2471-2482.

Sun X and Zhu S (1999). Structure and function of growth hormone. Foreign medical sciences. Section Pathophysiol. Clin. Med. 19: 6-9.

Yao J, Aggrey SE, Zadworny D, Hayes JF, et al. (1996). Sequence variations in the bovine growth hormone gene characterized by single-strand conformation polymorphism (SSCP) analysis and their association with milk production traits in Holsteins. Genetics 144: 1809-1816. 